\title{
The Effect of Innovation Network and Organizational Learning on Innovation Performance
}

\author{
Fang Shi ${ }^{1, a, \star}$, Yi-Min Gu ${ }^{1, b}$, Ji-Ming Zhu ${ }^{1, c}$, Li-Na Zheng ${ }^{1, d}$ \\ ${ }^{1}$ College of Economic and Management, Zhejiang University of Technology, Hangzhou 310023, \\ China \\ asf@zjut.edu.cn,b289971299@qq.com, 'bazhulan@163.com, dzln_4015@qq.com \\ ${ }^{*}$ Corresponding author
}

Keywords: High-tech enterprise, Innovation network, Organizational learning, Innovation performance.

\begin{abstract}
This research, based on the 228 high-tech enterprises of Zhejiang province, mainly studies effect mechanism of innovation network and organizational learning on the innovation performance. On the basis of forefathers' research, this paper has established the "innovation network - organizational learning-innovation performance" model and the related hypotheses are verified by the empirical analysis. Research shows that the innovation network scale of enterprises, network centrality can directly promote enterprise innovation performance, knowledge acquisition and the use of knowledge can also directly promote enterprise innovation performance and innovation network can promote the innovation performance of enterprises through knowledge acquisition and the use of knowledge indirectly, which shows that organizational learning has a partially intermediary effect for innovation network and innovation performance.
\end{abstract}

\section{Introduction}

Along with the economic globalization, the enterprise environment is in constant change, and the competition between enterprises is increasingly fierce. Therefore, enterprises must improve their innovation abilities to maintain their competitive advantages. At present, the enterprise innovation model has shifted from linear model to network model and the innovation process is becoming more and more complex, which makes enterprises difficult to rely on their own individual innovation. In this case, enterprises will need to rely on innovation network and make use of the effective knowledge from network to increase the success rate of innovation and improve the innovation performance. In addition, the globalization of innovation networks to improve organizational learning ability provides a good opportunity for enterprises. If enterprises lack organizational learning capability, the innovation model is difficult to transform and upgrade from the imitation innovation to independent innovation and enterprises will be difficult to form competitive advantages in the market. Therefore, how to make it a research current hotspot that innovation network has more effect on innovation performance through organizational learning for enterprises is also the major strategic issue for transformation and upgrading of enterprises.

\section{Relevant literature review and research framework}

\section{Main literature review}

At present, when the academia discusses where the enterprise's competitive advantages come from and how to obtain competitive advantages and other issues, the innovation network resources is one of the generally accepted theories. Enterprises can directly or indirectly absorb the resources needed from enterprise innovation network to provide security for enterprises to build competitive advantages. Nonaka and Takeuchi argued that innovation network was the set of all the formal and informal connections of the internal and external enterprise organization, which was used to absorb knowledge for organizations and was a tool to regulate organizational discipline. But in the current 
time, for the enterprises, the most important thing is not knowledge but the learning ability of knowledge [1]. Learning can help enterprises create meaningful knowledge which can be used by enterprises and be able to help enterprises improve their performance. Aragon-Correa defined organizational learning that organizational learning was a process for organization members to acquire, share and use the knowledge and was also a kind of ability of knowledge and experience accumulation [2]. In numerous researches of organizational learning, it can conclude four common points: Firstly, it emphasized on the importance of organization for knowledge acquisition and knowledge utilization in order to cope with external environment changes; Secondly, the organizational learning had a close relationship with organizational performance improvement and organization competitive ability maintaining; Thirdly, organizational learning was the dynamic process to improve organization performance by adjusting the organization behaviors and made permutation and combination of this dynamic process; Fourthly, the new information or new knowledge from the dynamic process should be applied to the day-to-day affairs of the organization. From the above study of the innovation network and organizational learning, it showed that its purpose was to improve organizational innovation performance. Innovation performance is the transformation relationship between enterprise innovation investment and the research result and development, which reflects the efficiency and effect of the technology innovation activities of enterprises or organizations. Freeman and Soete argued that innovation performance, in a narrow sense, referred to the process of making innovative products into the market, such as the speed of new products and new technology, etc [3]. Ahuja and Lampert argued that innovation performance, in the broadest sense, is the whole process of making the enterprise innovative products from the generation of the concept to the import for market. In this process, enterprises should not only focus on technology innovation, but also should focus on innovative product market prospect [4].

From the literature, it can be found that innovation performance is the foundation for enterprises to create and is the measurement for $\mathrm{s}$ to improve their innovation ability. Therefore, it is a difficult problem to study how to improve enterprise innovation performance. Starting from the enterprise innovation network and organizational learning to analyze its effect mechanism on innovation performance is a new research perspective. Enterprises absorb the effective knowledge from the innovation network which can help to improve the enterprise innovation performance. At the same time, the effective knowledge absorbed from the innovation network of enterprises can transform through the organizational learning to more effectively promote enterprise innovation performance. Therefore, it can be found the research perspective not only reflects direct increase of product innovation on enterprise benefits, but also reflects indirect increase of organizational learning on enterprise benefit.

\section{Research hypothesis and theoretical framework}

Relationship between innovation network and organizational learning. Organizational learning is the cyclic process that enterprises, in order to adapt to the dynamic changes of the external environment and keep the enterprise long-term competitive advantages, create, integrate and deliver the existing knowledge. Such a cycle is embedded in a specific network environment, influenced by the characteristics of organization itself, innovation network and a series of factors. Existing research showed that the more the connection relationship of enterprises in the innovation network, the greater the network scale of enterprises, and the more knowledge and information could the enterprises obtain from innovation networks [5]. Similarly, enterprises in the center of the network has higher status in the innovation network, which can have priority to absorb the knowledge in the network to improve the competitive advantage of enterprises and help enterprises to carry out more effective organizational learning[6]. Dyer and Nobeoka had carried on the investigation and analysis for Japanese Toyota motor company [7]. The study found that the company with high strength relationship with suppliers can more effectively deliver knowledge innovation, so that a better network strength can directly improve the Toyota to use suppliers' 
technology and promote the Toyota organizational learning. Bonner and Cavusgil had carried on the investigation and study on enterprises in the center of strategic network, and the results showed that enterprises with higher network center was actually the embodiment of enterprise network identity that the higher the status was, the more preferential could enterprises access to strategic information in the network[8]. Based on those, this article puts forward the following hypotheses:

Ha11: Innovation network scale has a positively promoting effect on knowledge acquisition.

Ha12: Innovation network scale has a positively promoting effect on knowledge platform construction.

Ha13: Innovation network scale has a positively promoting effect on knowledge utilization.

Ha21: Innovation network intensity has a positively promoting effect on knowledge acquisition.

Ha22: Innovation network intensity has a positively promoting effect on knowledge platform construction.

Ha23: Innovation network intensity has a positively promoting effect on knowledge utilization.

Ha31 Innovation network centrality has a positively promoting effect on knowledge acquisition.

Ha32: Innovation network centrality has a positively promoting effect on knowledge platform construction.

Ha33: Innovation network centrality has a positively promoting effect on knowledge utilization.

Relationship between organizational learning and innovation performance. Innovation relies on knowledge, whose essence is the process that the organization constantly learns new knowledge and creates new knowledge. By improving the organizational learning ability, enterprises provide constant power for the emergence of innovation performance. Batjargal argued that work experience, technical level and knowledge quantity of organization members was one of the important sources of enterprise innovation performance [9]. Alegrea and Chiva through the empirical study thought that the key for the success of enterprise innovation was that the enterprise was able to absorb the knowledge and apply to the development of new products [10]. Hong-ming Xie and Xiarong Zhang had carried out the on-the-spot investigation of 142 companies in south region of China, and the empirical results showed that the enterprise organizational learning had a obviously promoting effect on for enterprise management innovation and technological innovation [11]. Based on those, it puts forward the following hypotheses:

$\mathrm{Hb1}$ : Knowledge acquisition has a positively promoting effect on innovation performance.

$\mathrm{Hb} 2$ : Knowledge platform construction has a positively promoting effect on innovation performance.

Hb3: Knowledge utilization has a positively promoting effect on innovation performance.

Relationship between innovation network and innovation performance. Structure characteristics of innovation network affected the absorption, integration and utilization of knowledge of organizational members, thus influencing the innovation performance of the whole enterprises [12]. Rost argued that in the large-scale of innovation network, the strength of the enterprise innovation network, whether strong or weak combination relationship, could more easily acquire information and resources needed for organizational learning from innovation network [13]. Ferrianiv argued that enterprises with higher network centrality had stronger stability and could be easier to form partnerships with other innovative enterprises [14]. Based on those, it puts forward the following hypotheses:

Hc1: Innovation network size has a positive promoting effect on innovation performance.

Hc2: Innovation network intensity has a positive promoting effect on innovation performance.

Hc3: Innovation network centrality has a positive promoting effect on innovation performance.

Mediated relation of organizational learning. A considerable amount of research makes the organizational learning as an intervening variable between enterprise innovation network and innovation performance. Pan Wenan argued that resources obtained from the innovation network could help enterprises to improve their innovation performance, but the increase depended on the 
organization learning ability for knowledge [15]. Xu Guanna used Chinese manufacturing enterprises as research samples and the results showed that organizational learning was the key intermediary variable of innovation network affecting the enterprise technology innovation performance [16]. Hong-bin dou also had carried on the empirical study and thought that organizational learning have complete intermediary effect between innovation network in each feature dimension on enterprise innovation performance [17]. Based on those, it puts forward the following hypotheses:

Hd11: Knowledge acquisition plays an intermediary role between the relationship of innovation network scale and innovation performance.

Hd12: Knowledge acquisition plays an intermediary role between the relationship of innovation network strength and innovation performance.

Hd13: Knowledge acquisition plays an intermediary role between the relationship of innovation network centrality and innovation performance.

Hd21: Knowledge platform construction plays an intermediary role between the relationship of innovation network scale and innovation performance.

Hd22: Knowledge platform construction plays an intermediary role between the relationship of innovation network strength and innovation performance.

Hd23: Knowledge platform construction plays an intermediary role between the relationship of innovation network centrality and innovation performance.

Hd31: Knowledge utilization plays an intermediary role between the relationship of innovation network scale and innovation performance.

Hd32: Knowledge utilization plays an intermediary role between the relationship of innovation network strength and innovation performance.

Hd33: Knowledge utilization plays an intermediary role between the relationship of innovation network centrality and innovation performance.

\section{Research design}

\section{Research sample}

This article adopts the method of questionnaire survey for empirical research and high and new technology enterprises in Zhejiang province as investigation object to measure related variables of innovation network, organizational learning and innovation performance. It distributes 480 questionnaires and gets back 287 questionnaires, whose recovery rate is $59.8 \%$. After screening and eliminating invalid questionnaires, it has 228effective questionnaires, whose rate of valid questionnaire is $79.4 \%$. The sample covers all 11 cities of Zhejiang province, which shows comprehensiveness of the survey data. In enterprise scale statistics, enterprises with more than 50 account for $78.51 \%$ and enterprises setting up more than 10 years account for $46.49 \%$, which indicates the representative of the survey data. From the statistical data, the research and development personnel accounts for $22.53 \%$ of total employee number of 228 enterprises, enterprise $R \& D$ expenses account for $8.34 \%$ of the total sales revenue in three years, and the number of respondents above middle managers position account for $86.58 \%$, which shows the reliability of the survey data.

\section{Reliability and validity of data}

It uses Cronbach's Alpha value to verify study reliability. Table 1 shows Cronbach's Alpha values of all variables that the results are all greater than 0.9 with high reliability.

It uses KMO and Bart riley sphere to test research validity that the KMO values of the innovation network, organizational learning and innovation performance are respectively $0.933,0.933$ and 0.933 and significance level of Bart riley is 0.000 , which reaches the validity testing standard. 
Tab.1 Reliability analysis of research variables

\begin{tabular}{|c|c|c|c|c|c|}
\hline Variable & Item & Mean & $\begin{array}{l}\text { Standard } \\
\text { deviation }\end{array}$ & $\begin{array}{l}\text { Factor } \\
\text { loading } \\
\text { coefficient }\end{array}$ & $\begin{array}{l}\text { Cronbach's } \\
\text { Alpha value }\end{array}$ \\
\hline \multirow{4}{*}{ Network scale } & $\begin{array}{l}\text { Number of scientific research } \\
\text { institutions cooperated with }\end{array}$ & 3.43 & 1.028 & 0.930 & \multirow{4}{*}{0.941} \\
\hline & $\begin{array}{l}\text { Number of other enterprises } \\
\text { cooperated with }\end{array}$ & 3.43 & 1.045 & 0.923 & \\
\hline & $\begin{array}{l}\text { Number of suppliers cooperated } \\
\text { with }\end{array}$ & 3.46 & 1.104 & 0.919 & \\
\hline & $\begin{array}{l}\text { Number of major customers } \\
\text { cooperated with }\end{array}$ & 3.47 & 1.060 & 0.916 & \\
\hline \multirow{4}{*}{ Network intensity } & $\begin{array}{l}\text { Frequency of cooperation with } \\
\text { scientific research institutions }\end{array}$ & 3.66 & 0.996 & 0.918 & \multirow{4}{*}{0.934} \\
\hline & $\begin{array}{l}\text { Frequency of cooperation with } \\
\text { other enterprises }\end{array}$ & 3.62 & 0.993 & 0.910 & \\
\hline & $\begin{array}{l}\text { Frequency of cooperation with } \\
\text { suppliers }\end{array}$ & 3.62 & 1.010 & 0.915 & \\
\hline & $\begin{array}{l}\text { Frequency of cooperation with } \\
\text { major customers }\end{array}$ & 3.57 & 1.058 & 0.913 & \\
\hline \multirow{4}{*}{$\begin{array}{l}\text { Network } \\
\text { centrality }\end{array}$} & With high visibility & 3.82 & 0.985 & 0.876 & \multirow{4}{*}{0.909} \\
\hline & With rich network information & 3.57 & 0.938 & 0.887 & \\
\hline & Firm network connection & 3.61 & 0.990 & 0.878 & \\
\hline & $\begin{array}{l}\text { More information in network to } \\
\text { company }\end{array}$ & 3.57 & 0.895 & 0.884 & \\
\hline \multirow{4}{*}{$\begin{array}{l}\text { Knowledge } \\
\text { acquisition }\end{array}$} & $\begin{array}{l}\text { Getting information about new } \\
\text { products }\end{array}$ & 3.91 & 0.989 & 0.843 & \multirow{4}{*}{0.943} \\
\hline & $\begin{array}{l}\text { Using existing knowledge to } \\
\text { create new knowledge }\end{array}$ & 3.89 & 1.023 & 0.863 & \\
\hline & Active learning of employees & 3.83 & 1.019 & 0.847 & \\
\hline & $\begin{array}{l}\text { Getting new product } \\
\text { development process }\end{array}$ & 3.84 & 0.958 & 0.879 & \\
\hline \multirow{4}{*}{$\begin{array}{l}\text { Knowledge } \\
\text { platform } \\
\text { construction }\end{array}$} & $\begin{array}{l}\text { With perfect information } \\
\text { infrastructure }\end{array}$ & 3.64 & 0.917 & 0.900 & \multirow{4}{*}{0.925} \\
\hline & $\begin{array}{c}\text { Frequency of knowledge } \\
\text { platform data updating }\end{array}$ & 3.58 & 0.942 & 0.901 & \\
\hline & $\begin{array}{l}\text { Knowledge platform providing } \\
\text { support for knowledge exchange }\end{array}$ & 3.56 & 0.896 & 0.902 & \\
\hline & $\begin{array}{l}\text { Integrating and transforming } \\
\text { knowledge of knowledge } \\
\text { platform }\end{array}$ & 3.61 & 0.944 & 0.905 & \\
\hline \multirow{4}{*}{$\begin{array}{l}\text { Knowledge } \\
\text { utilization }\end{array}$} & $\begin{array}{l}\text { Using new knowledge to } \\
\text { improve product }\end{array}$ & 3.56 & 0.998 & 0.915 & \multirow{4}{*}{0.935} \\
\hline & $\begin{array}{c}\text { Proper use of knowledge of the } \\
\text { past }\end{array}$ & 3.57 & 1.010 & 0.913 & \\
\hline & $\begin{array}{l}\text { Encouraging employees to use } \\
\text { new knowledge }\end{array}$ & 3.62 & 1.001 & 0.923 & \\
\hline & $\begin{array}{l}\text { Using new knowledge to } \\
\text { improve the management and } \\
\text { planning in the future }\end{array}$ & 3.66 & 1.056 & 0.910 & \\
\hline \multirow{5}{*}{$\begin{array}{l}\text { Innovation } \\
\text { performance }\end{array}$} & New product development speed & 3.71 & 0.941 & 0.902 & \multirow{5}{*}{0.920} \\
\hline & Authorized patents number & 3.65 & 0.919 & 0.904 & \\
\hline & New products number & 3.71 & 0.946 & 0.897 & \\
\hline & New product market share & 3.68 & 0.905 & 0.905 & \\
\hline & $\begin{array}{l}\text { Proportion of New products } \\
\text { output value on total sales }\end{array}$ & 3.66 & 0.928 & 0.902 & \\
\hline
\end{tabular}




\section{Empirical analyses}

\section{Correlation analysis}

The correlation analysis of all the variables involved in the research model is shown in table 2 . Analysis results indicate that there are significant positive correlations between network scale, network strength, network centrality, knowledge acquisition, knowledge platform construction, and knowledge utilization and innovation performance.

Tab.2 Correlation relationship between the variables

\begin{tabular}{|c|c|c|c|c|c|c|c|}
\hline Variable & $\mathrm{a} 1$ & $\mathrm{a} 2$ & $\mathrm{a} 3$ & $\mathrm{~b} 1$ & $\mathrm{~b} 2$ & $\mathrm{~b} 3$ & $\mathrm{C}$ \\
\hline a1 Network scale & 1 & $0.596^{* *}$ & $0.625^{* *}$ & $0.530^{* *}$ & $0.496^{* *}$ & 1 & $0.596^{* *}$ \\
\hline a2 Network intensity & $0.596^{* *}$ & 1 & $0.695^{* *}$ & $0.663^{* *}$ & $0.645^{* *}$ & $0.596^{* *}$ & 1 \\
\hline a3 Network centrality & $0.625^{* *}$ & $0.695^{* *}$ & 1 & $0.637^{* *}$ & $0.542^{* *}$ & $0.625^{* *}$ & $0.695^{* *}$ \\
\hline b1 Knowledge acquisition & $0.530^{* *}$ & $0.663^{* *}$ & $0.637^{* *}$ & 1 & $0.645^{* *}$ & $0.530^{* *}$ & $0.663^{* *}$ \\
\hline b2 Knowledge platform construction & $0.496^{* *}$ & $0.645^{* *}$ & $0.542^{* *}$ & $0.645^{* *}$ & 1 & $0.496^{* *}$ & $0.645^{* *}$ \\
\hline b3 Knowledge utilization & $0.571^{* *}$ & $0.645^{* *}$ & $0.622^{* *}$ & $0.588^{* *}$ & $0.615^{* *}$ & $0.571^{* *}$ & $0.645^{* *}$ \\
\hline c Innovation performance & $0.590^{* *}$ & $0.614^{* *}$ & $0.649^{* *}$ & $0.662^{* *}$ & $0.584^{* *}$ & $0.590^{* *}$ & $0.614^{* *}$ \\
\hline
\end{tabular}

Note: $* *$ represents significance level $p<0.01$.

\section{Model construction and fitting}

Based on the theoretical framework and related research hypotheses, it builds the initial structural equation model. The model measures 3 exogenous latent variables through 12 exogenous manifest variables, and sets up 17 endogenous manifest variables to measure 4 endogenous latent variables, thus verifying the research hypotheses path of innovation network effecting enterprise innovation performance through organizational learning in the model of Zhejiang province high and new technology enterprises.

Tab.3 Model fitting results after correction

\begin{tabular}{|c|c|c|c|c|c|}
\hline Path & $\begin{array}{l}\text { Standard path } \\
\text { coefficient }\end{array}$ & C.R. & $\mathrm{P}$ & $\begin{array}{l}\text { Corresponding } \\
\text { hypotheses }\end{array}$ & Validating \\
\hline Knowledge acquisition $\longleftarrow$ Network scale & 0.120 & 2.106 & 0.035 & Ha11 & Pass \\
\hline $\begin{array}{l}\text { Knowledge platform construction } \leftarrow \text { Network } \\
\text { scale }\end{array}$ & 0.141 & 2.398 & 0.016 & Ha12 & Pass \\
\hline Knowledge utilization $\leftarrow$ Network $\quad$ scale & 0.249 & 4.139 & $* * *$ & Ha13 & Pass \\
\hline Knowledge acquisition $\longleftarrow$ Network intensity & 0.513 & 8.258 & $* * *$ & Ha21 & Pass \\
\hline $\begin{array}{l}\text { Knowledge platform construction } \leftarrow \text { Network } \\
\text { intensity }\end{array}$ & 0.593 & 9.015 & $* * *$ & Ha22 & Pass \\
\hline Knowledge utilization $\longleftarrow$ Network intensity & 0.467 & 7.352 & $* * *$ & $\mathrm{Ha} 23$ & Pass \\
\hline Knowledge acquisition $\leftarrow$ Network centrality & 0.381 & 6.259 & $* * *$ & Ha31 & Pass \\
\hline $\begin{array}{l}\text { Knowledge platform construction } \leftarrow \text { Network } \\
\text { centrality }\end{array}$ & 0.180 & 3.007 & 0.003 & Ha32 & Pass \\
\hline Knowledge utilization $\leftarrow$ Network centrality & 0.328 & 5.277 & $* * *$ & Ha33 & Pass \\
\hline Innovation performance $\leftarrow$ Network scale & 0.179 & 3.133 & 0.002 & $\mathrm{Hb} 1$ & Pass \\
\hline Innovation performance $\leftarrow$ Network intensity & & & & $\mathrm{Hb} 2$ & Not pass \\
\hline Innovation performance $\leftarrow$ Network centrality & 0.195 & 3.107 & 0.002 & $\mathrm{Hb} 3$ & Pass \\
\hline $\begin{array}{c}\text { Innovation performance } \leftarrow \text { Knowledge } \\
\text { acquisition }\end{array}$ & 0.299 & 4.576 & $* * *$ & Hc1 & Pass \\
\hline $\begin{array}{l}\text { Innovation performance } \leftarrow \text { Knowledge } \\
\text { platform construction }\end{array}$ & & & & Hc2 & Not pass \\
\hline $\begin{array}{c}\text { Innovation performance } \leftarrow \text { Knowledge } \\
\text { utilization }\end{array}$ & 0.385 & 5.634 & $* * *$ & Hc3 & Pass \\
\hline$c^{2} / d f=2.066$ & \multicolumn{2}{|c|}{$\mathrm{P}=0.000$} & \multicolumn{3}{|c|}{ RMSEA $=0.069$} \\
\hline $\mathrm{IFI}=0.939$ & \multicolumn{2}{|c|}{$\mathrm{CFI}=0.938$} & \multicolumn{3}{|c|}{ TLI $=0.931$} \\
\hline
\end{tabular}

Note: $* * *$ represents significance level $p<0.001$

Using AMOS statistics software to make analysis calculation of the initial structural equation model established, the $c^{2} / d f$ value of the model is 2.075 , CFI, TLI, IFI values are all greater than 0.9 and RMSEA value is less than 0.08 , which shows that the degree of fitting of the initial model is 
good and conforms to the requirement of the model. But there are parts of the path not reaching significance level and not passing the test, such as the path coefficient of "innovation performance $\leftarrow$ network intensity" and the path coefficients of "innovation performance $\leftarrow$ knowledge platform". The research shows that when the inadequacy of initial structure model makes internal definition and causes failures of path coefficient, it can be improved through continuous correction of the model. Therefore, it deletes two paths that are not significant in order to achieve the purpose of correction of the model. After the correction , the $c^{2} / d f$ value of the model degree of fitting is 2.066, CFI, TLI, IFI values are greater than 0.9 and RMSEA value is less than 0.08 , which shows that the model degree of fitting corrected is good and conforms to the requirements of the model. The table 3 shows that there are 13 paths whose $\mathrm{P}$ values in less than 0.05 levels are significant among variables.

\section{Model explanation}

The final model path effect can be seen in table 4. As you can see, the innovation network scale and the network centrality of Zhejiang province high and new technology enterprises have a direct effect on enterprise innovation performance, and the network intensity has no direct effect on enterprise innovation performance, but it can have a positive effect on innovation performance by knowledge acquisition and knowledge utilization. Meanwhile, the network scale and network centrality can also have a positive effect on innovation performance by knowledge acquisition and knowledge utilization, which also shows that the knowledge acquisition and knowledge utilization have played a very good role of mediation, which verifies the hypotheses of Hd11, Hd12, Hd13, $\operatorname{Hd} 31, \operatorname{Hd} 32, \mathrm{Hd} 33$, but research hypotheses $\operatorname{Hd} 21, \operatorname{Hd} 22, \operatorname{Hd} 23$ do not pass.

Tab.4 Effect decomposition of the final path model

\begin{tabular}{|c|c|c|c|c|c|c|c|}
\hline $\begin{array}{l}\text { Effect } \\
\text { type }\end{array}$ & Outcome variable & $\begin{array}{l}\text { Network } \\
\text { scale }\end{array}$ & $\begin{array}{l}\text { Network } \\
\text { intensity }\end{array}$ & $\begin{array}{l}\text { Network } \\
\text { centrality }\end{array}$ & $\begin{array}{l}\text { Knowledge } \\
\text { acquisition }\end{array}$ & $\begin{array}{c}\text { Knowledge } \\
\text { platform } \\
\text { construction }\end{array}$ & $\begin{array}{l}\text { Knowledge } \\
\text { utilization }\end{array}$ \\
\hline \multirow{4}{*}{$\begin{array}{l}\text { Direct } \\
\text { effect }\end{array}$} & $\begin{array}{l}\text { Knowledge } \\
\text { acquisition }\end{array}$ & 0.120 & 0.513 & 0.381 & 0.000 & 0.000 & 0.000 \\
\hline & $\begin{array}{c}\text { Knowledge } \\
\text { platform } \\
\text { construction }\end{array}$ & 0.141 & 0.593 & 0.180 & 0.000 & 0.000 & 0.000 \\
\hline & $\begin{array}{c}\text { Knowledge } \\
\text { utilization }\end{array}$ & 0.249 & 0.467 & 0.328 & 0.000 & 0.000 & 0.000 \\
\hline & $\begin{array}{c}\text { Innovation } \\
\text { performance }\end{array}$ & 0.179 & 0.000 & 0.195 & 0.299 & 0.0000 & 0.385 \\
\hline \multirow{4}{*}{$\begin{array}{l}\text { Indire } \\
\text { ct } \\
\text { effect }\end{array}$} & $\begin{array}{l}\text { Knowledge } \\
\text { acquisition }\end{array}$ & 0.000 & 0.000 & 0.000 & 0.000 & 0.000 & 0.000 \\
\hline & $\begin{array}{c}\text { Knowledge } \\
\text { platform } \\
\text { construction }\end{array}$ & 0.000 & 0.000 & 0.000 & 0.000 & 0.000 & 0.000 \\
\hline & $\begin{array}{c}\text { Knowledge } \\
\text { utilization }\end{array}$ & 0.000 & 0.000 & 0.000 & 0.000 & 0.000 & 0.000 \\
\hline & $\begin{array}{c}\text { Innovation } \\
\text { performance }\end{array}$ & 0.132 & 0.333 & 0.240 & 0.00 & 0.00 & 0.00 \\
\hline \multirow{4}{*}{$\begin{array}{l}\text { Total } \\
\text { effect }\end{array}$} & $\begin{array}{l}\text { Knowledge } \\
\text { acquisition }\end{array}$ & 0.120 & 0.513 & 0.381 & 0.000 & 0.000 & 0.000 \\
\hline & $\begin{array}{c}\text { Knowledge } \\
\text { platform } \\
\text { construction }\end{array}$ & 0.141 & 0.593 & 0.180 & 0.000 & 0.000 & 0.000 \\
\hline & $\begin{array}{l}\text { Knowledge } \\
\text { utilization }\end{array}$ & 0.249 & 0.467 & 0.328 & 0.000 & 0.000 & 0.000 \\
\hline & $\begin{array}{l}\text { Innovation } \\
\text { performance }\end{array}$ & 0.311 & 0.333 & 0.435 & 0.299 & 0.0000 & 0.385 \\
\hline
\end{tabular}

\section{Results analysis}

Firstly, three characteristic dimensions of innovation network of innovation network scale, network intensity, and network centrality have significantly positive promoting effect on three characteristic dimensions of organizational learning of knowledge acquisition, knowledge platform 
construction and knowledge utilization, showing that the more relations of cooperation with other partners the enterprises have in the innovation network, the higher the frequency of communication is and the higher the popularity is, the more can they promote the organization learning.

Secondly, knowledge acquisition and knowledge utilization of organizational learning have positively promoting effects on enterprise innovation performance, while knowledge platform construction has no significant effect on enterprise innovation performance. The reason may be as follows: on the one hand, the enterprise knowledge platform construction is a store for innovation network resources, and the storage of resources needs integration, transformation and utilization to have a positively promoting effect on innovation performance; On the other hand, the resources belong to the internal resources of enterprises, which are confidential sources of competition for enterprises. Once external enterprises get these resources, it will damage the enterprise competition ability. Therefore, general staff may be difficult to gain access to the core resources, which leads to the waste of resources and reduce its promoting effect on innovation performance.

Thirdly, the innovation network scale and the network centrality of innovation network have positively promoting effects on enterprise innovation performance, while network intensity has no significant effect on innovation performance. The reason may be that in the high intensity of innovation network enterprises will strengthen the protection of the core resources in order to maintain their own innovation advantages, thus affecting the focus of enterprises for effective absorption of knowledge; On the other hand, the greater the strength of enterprise network is, the network connection relation formed tends towards the weak links, so it is difficult to obtain other enterprise resources effectively. In addition, the greater the innovation network of enterprise is, the more the noises are, which will cause huge waste of the resources, which the reason why enterprise innovation network intensity has no significant effect on innovation performance.

Finally, the enterprise innovation network scale and network centrality can positively promote innovation performance, while there is no significant effect relationship between innovation network intensity and innovation performance. But the innovation network can have a effect on innovation performance through the different impact of organizational learning. It also shows that the knowledge acquisition and knowledge utilization play intermediary roles in the process of innovation network affecting on innovation performance. Because the knowledge platform construction has no significant effect on innovation performance and the intermediary function is also not true, it may need to join other adjustment variables for subsequent research.

\section{Conclusion}

Using high-tech enterprises in Zhejiang province as the research sample, and the effect of enterprise innovation network and organizational learning on innovation performance as the theme, it uses SPSS17.0 and AMOS statistics software to carried on the empirical analysis, and establishes the analytical framework of "innovation network - organizational learning - innovation performance", which obtains certain theoretical value and practical significance of the research conclusion. After a rapid development in recent years, Zhejiang province high-tech enterprises have gradually got into the key stage of change of the pattern of economic development and industrial structure optimization. With the fierce competition, enterprises face with important issues about how to improve enterprise innovation performance and keep the sustainable development of enterprises. Based on the changes of enterprise competition environment and combined with empirical research results, it put forward the following countermeasure and suggestion for high and new technology enterprises in Zhejiang province at the present stage.

Firstly, enterprises should build innovation network scientifically and improve the enterprise ability to obtain innovation resources. Zhejiang province high and new technology enterprises, in the process of management, should adopt more flexible innovation network plan, and change the strategy that relying on innovation imitation or single internal research and development in the past, 
and then turns to have the market-oriented center to form a cooperative innovation relations and cooperation with enterprises in accordance with the enterprise innovation process. The foreign cooperation relationships include the following several characteristics: Firstly, the enterprise can not only take the customer as the center, but also need to focus on cooperation with other research institutions, enterprises, suppliers and so on to fully expand the scale of the enterprise innovation network; Secondly, enterprises should establish appropriate intensity of network relations and increase cooperation frequency with innovation partners to promote the flow of knowledge and information with internal innovation network diversity and heterogeneity. Finally, enterprises should shape the center position in the innovation network. If enterprises is in the position of the innovation network edge, they will not be able to effectively obtain market opportunity, Therefore, enterprises, carrying out innovation activities in the innovation network, should improve the innovation network centrality in their own good fields, so as to make more resources available from the innovation network.

Secondly, enterprises should strengthen organizational learning and improve the efficiency of knowledge transformation. Enterprises should fully recognize the importance of organizational learning and put organizational learning on enterprise strategic position of improving innovation performance. First of all, enterprises must set up the learning organization culture, and cultivate the learning spirit of organization member to make efforts to promote enterprise to build learning organization. Secondly, enterprises should provide learning of organization with good information infrastructure, make full use of computer technology, and provide professional knowledge platform, on the basis of the guarantee of hardware facilities to vigorously introduce the corresponding technology innovation talents and improve the organization software facilities. Finally, enterprises should balance three aspects of resource allocation of knowledge acquisition, knowledge platform construction and knowledge utilization. Any a way of learning need to rationalize, otherwise it will lead to resource use efficiency decline.

Thirdly, selecting innovation model and promoting enterprise innovation performance. Enterprises, in technology innovation activities, if pay too much attention to a particular innovation model, it will fall into the trap of technological innovation. In order to make Zhejiang province high and new technology enterprises sustainable development, enterprises must select reasonable innovation modes in different stages of development. First of all, if the enterprise innovative products are in the initial stage, the enterprise should make technology innovation and research and development as the center to make full use of the innovation network resources and improve the success rate of innovation behaviors through organizational learning. Secondly, if the enterprise innovative products are in the mature stage, the enterprise will need to keep its own competitiveness of core technology and make itself market-oriented to develop innovative products to meet the market demands, so as to improve the market share of innovative products and expand the leading product market position. Finally, if the enterprise innovation products are in a recession stage, the enterprise will need to focus on breakthrough innovation research and development activities to develop new core products to replace the original main products and keep the enterprise competitive ability.

\section{Acknowledgement}

This research was financially supported by the Soft Science Plan of Zhejiang Province in China (2013C25027).

\section{Reference}

[1] Nonaka, I.and Takeuchi, H. The knowledge-creating company: How Japanese companies create the dynamics of innovation [J]. Harvard Business Review, 69 (1995) 96-104. 
[2] Aragon-Correa, J, A.and Rubio-López, E. Proactive corporate environmental strategies: myths and misunderstandings [J]. Long Range Planning, 40(3) (2007) 357-381.

[3] Freeman, C.and Soete, L. The economics of industrial innovation [M]. London: Psychology Press, 1997.

[4] Ahuja, G.and Morris, L, C. Entrepreneurship in the large corporation: A longitudinal study of how established firms create breakthrough inventions [J]. Strategic Management Journal, 22(6-7) (2001) 521-543.

[5] Koka, B, R.and Prescott, J, E. Strategic alliances as social capital: A multidimensional view [J]. Strategic management journal, 23(9) (2002) 795-816.

[6] Tsai, W. Knowledge transfer in intraorganizational networks: Effects of network position and absorptive capacity on business unit innovation and performance [J]. Academy of management journal, 44(5) (2001)996-1004.

[7] Dyer, J.and Nobeoka, K. Creating and managing a high performance knowledge-sharing network: the Toyota case [J]. Strategic Management Journal: Strategic Networks, 21(3) (2000)345367.

[8] Bonner, J, M., Kim, D.and Cavusgil, S, T. Self-perceived strategic network identity and its effects on market performance in alliance relationships [J]. Journal of Business Research, 58(10) (2005)1371-1380.

[9] Batjargal, B. Internet entrepreneurship: social capital, human capital, and performance of internet ventures in China [J]. Research Policy, 36(5) (2007)605-618.

[10] Alegre,J.and Chiva, R. Assessing the impact of organizational learning capability on product innovation performance: An empirical test[J]. Technovation, 28(6) (2008)315-326.

[11] Xie Hong-ming, Zhang Xiarong and Cheng Cong etc. The effect research of network relation intensity, enterprise learning ability on technology innovation [J]. Journal of scientific research management, 2(2012)55-62.

[12] Corey, G. Theory and practice of group counseling [M]. London: Cengage Learning, 2011.

[13] Rost, K. The strength of strong ties in the creation of innovation [J]. Research Policy, 40(4) (2011) 588-604.

[14] Ferriani, S. A core/periphery perspective on individual creative performance: Social networks and cinematic achievements in the Hollywood film industry [J]. Organization Science, 19(6) (2008) 824-844.

[15] Pan Wenan. Research on relationship strength, knowledge integration capability and efficiency transfer of supply chain knowledge [J]. Journal of scientific research management, 1(2012) 147-153.

[16] Xu Guanna, Zhou Yuan and Liu Xuefeng. Mechanism case studies of relationship embeddedness on technology innovation performance [J]. Science, 29 (11) (2011) 1728-1735.

[17] Dou Hongbin, Wang Zhengbin. The influence research of network structure on firm growth performance-intermediation of exploitative learning and explorative learning [J]. Nankai management review, 14 (3) (2011)15-25. 